\title{
Cloning and expression of Saccharomyces cerevisiae SUC2 gene in yeast platform and characterization of recombinant enzyme biochemical properties
}

\author{
Nooshin Mohandesi $^{1} \cdot$ Seyed Omid Ranaei Siadat ${ }^{2} \cdot$ Kamahldin Haghbeen $^{1}$ • \\ Ardeshir Hesampour ${ }^{3}$
}

Received: 8 February 2016/Accepted: 25 May 2016/Published online: 8 June 2016

(c) The Author(s) 2016. This article is published with open access at Springerlink.com

\begin{abstract}
Invertase (EC.3.2.1.26) catalyzes the hydrolysis of sucrose to an equimolar mixture of D-glucose and D-fructose which is of interest for various industrial applications. In this research, Saccharomyces cerevisiae invertase gene (SUC2) was optimized based on Pichia pastoris codon preference. The synthetic gene was introduced into the methylotrophic yeast Pichia pastoris under the control of the inducible AOX1 promoter. High level of the extracellular recombinant invertase (R-inv) production was achieved via methanol induction for 4 days and purified by His-Tag affinity chromatography which appeared to be a mixture of glycosylated proteins with various sizes of 85-95 kDa on SDS-PAGE. Deglycosylation of the proteins by Endo-H resulted in the proteins with average molecular weight of $60 \mathrm{kDa}$. The purified recombinant invertase biochemical properties and kinetic parameters determined a $\mathrm{pH}$ and temperature optimum at 4.8 and $60{ }^{\circ} \mathrm{C}$, respectively, which in comparison with native $S$. cerevisiae invertase, thermal stability of recombinant invertase is highly increased in different heating treatment experiments. The purification of recombinant invertase resulted in an enzyme with specific activity of $178.56 \mathrm{U} / \mathrm{mg}$ with 3.83-fold of purification and the kinetic constants for enzyme were $\mathrm{Km}$ value of $19 \mathrm{mM}$ and Vmax value of $300 \mu \mathrm{mol} \mathrm{min}{ }^{-1} \mathrm{mg}^{-1}$ With kinetic efficiency $(\mathrm{Kcat} / \mathrm{Km})$
\end{abstract}

Seyed Omid Ranaei Siadat

o_ranaei@sbu.ac.ir

1 National Institute of Genetic Engineering and Biotechnology (NIGEB), Tehran, Islamic Republic of Iran

2 Protein Research Centre, Shahid Beheshti University, GC, Tehran, Islamic Republic of Iran

3 Department of Biology, Central Tehran Branch, Islamic Azad University, Tehran, Islamic Republic of Iran of $13.15 \mathrm{~s}^{-1} \mathrm{mmol}^{-1}$ it can be concluded that recombinant $P$. pastoris invertase can be more effective for industrial quality criteria. We conclude that recombinant $P$. pastoris enzyme with broad $\mathrm{pH}$ stability, substrate specificity and proper thermal stability can fulfil a series of predefined industrial quality criteria to be used in food, pharmaceutical and bio ethanol production industries.

Keywords Saccharomyces cerevisiae - Recombinant invertase $\cdot$ Pichia pastoris $\cdot$ SUC2 gene $\cdot$ Cloning

\section{Introduction}

Invertases $[\beta$-D-fructofuranoside fructohydrolase (EC 3.2.1.26)] are disaccharidases which belong to the Gh32 family of glycoside hydrolases and catalyse the hydrolysis of sucrose into an equimolar mixture of D-glucose and Dfructose. To produce invert sugar at concentrations lower than $10 \%$ sucrose that are more stable than pure sucrose syrups and with less carbohydrate are sweeter than sucrose and minimise crystallisation in comparison with sucrose at high (Gehlawat 2001; Boer et al. 2004; Mona et al. 2009; Patil et al. 2012) concentration. They have been reported to be produced by variety of higher plants, some animal cells and wide range of microorganisms including bacteria and fungi (Kim et al. 2000).

The Production of invert sugar and high fructose syrup from sucrose by acid hydrolysis method is uneconomic, because of its low conversion efficiency $(65-70 \%)$ and formation of undesirable products (7-8\%) (Kaur and Sharma 2005; Shankar et al. 2014). Therefore, biological sources due to their easy cultivation, high yields of producing enzyme and ability to hydrolyse sucrose by a single step are remarkable alternatives. 
Preparation of invert sugar and high fructose syrup by acting on broad cost effective substrate spectrum such as sucrose, sugarcane bagasse, molasses and grape juice residue making invertase suitable for biotechnological applications and due to its interesting functional properties (Kaur and Sharma 2005; Gracida-Rodriguez et al. 2006; Mona et al. 2009; Driouch et al. 2010), the market potential of invertases includes applications in food and dairy industries, pharmaceutical, cosmetic, paper and tobacco industries, production of confectionary with liquid center, bakery, calf feed preparation and fermentation of cane molasses into ethanol. Also, increasing disturbances on pollution that occurs from industrial wastes, has encouraged interest in converting waste materials to useful products using invertase (Gehlawat 2001; Kaur and Sharma 2005; Gracida-Rodriguez et al. 2006; Mona et al. 2009; Driouch et al. 2010; Uma et al. 2010a, b; Shankar et al. 2014). Invertase production from native sources cannot persuade the increasing market demand due to low yields which is not compatible with the industrial fermentation processes (Cereghino and Cregg 2000; Piscitelli et al. 2010). Recombinant protein expression in cost effective cultivable and handling host can provide higher productivity in short period of time with low costs. Regarding this effect on industry, increasing the level of invertase expression is considerable. Despite the success in using Saccharomyces cerevisiae as a host for expression of eukaryotic genes, some problems like hyperglycosylation, less secretion of recombinant protein and low level of expression reduce its potential in biotechnological industry. For these reasons, instead of $S$. cerevisiae, methylotrophic yeast systems such as Pichia pastoris because of correct glycosylation profile, cost effective bulk recombinant protein production, high level expression, secretion of heterologous protein to media and easy scale up expression which is important for biotechnological industry, have been used (Cereghino and Cregg 2000). The objective of this work was to investigate the expression and extracellular production of recombinant invertase of optimized $S U C 2$ gene from the source of $S$. cerevisiae which was expressed in methylotrophic yeast $P$. pastoris. Expression of the optimized $S U C 2$ gene in $P$. pastoris yields a secreted active recombinant protein with a little different molecular weight to the invertase secreted by $S$. cerevisiae, after purification of enzyme, biochemical properties and kinetic parameters of purified recombinant invertase was determined.

\section{Materials and methods}

\section{Strains, plasmid, growth conditions}

Escherichia coli strain DH5 $\alpha$ was used for bacterial transformation and plasmid propagation. E. coli strain DH5 $\alpha$ was grown in Luria-Bertani (LB) medium [(1 \% (w/ v) yeast extract, $2 \%(\mathrm{w} / \mathrm{v})$ peptone, $1 \%(\mathrm{w} / \mathrm{v}) \mathrm{NaCl}]$ at $37{ }^{\circ} \mathrm{C}$ and supplemented with ampicillin $(100 \mu \mathrm{g} / \mathrm{ml})$ for Screening of Transformants.

Pichia pastoris strain 4 was employed as a protein expression host in this work and expression vector pPink $\alpha$ $\mathrm{HC}(7.9 \mathrm{~kb})$ were obtained from Invitrogen, (San Diego, CA). Yeasts were cultivated in Yeast extract Peptone Dextrose (YPD) medium (1\% yeast extract, $2 \%$ peptone, $2 \%$ glucose at $30{ }^{\circ} \mathrm{C}$ (Table 1 ). For expression of recombinant enzyme, transformed $P$. pastoris was incubated in buffered glycerol-complex (BMGY) medium $(0.1 \mathrm{M}$ sodium phosphate $\mathrm{pH} 6.0,1 \%(\mathrm{w} / \mathrm{v})$ yeast extract, $2 \%(\mathrm{w} / \mathrm{v})$ peptone, $1.34 \%(\mathrm{w} / \mathrm{v})$ yeast nitrogen base (YNB), $0.00004 \%(\mathrm{w} / \mathrm{v})$ biotin, and $1 \%(\mathrm{v} / \mathrm{v})$ glycerol) at $30{ }^{\circ} \mathrm{C}$ in shaker at $200 \mathrm{rpm}$. For induction of invertase gene expression by methanol was used by buffered methanolcomplex (BMMY) medium [0.1 M sodium phosphate $\mathrm{pH}$ $6.0,1 \%(\mathrm{w} / \mathrm{v})$ yeast extract, $2 \%(\mathrm{w} / \mathrm{v})$ peptone, $1.34 \%$
Table 1 Strains, plasmids and synthetic oligonucleotide primers

\begin{tabular}{|c|c|c|}
\hline Item & Description & Reference \\
\hline \multicolumn{3}{|l|}{ Strains } \\
\hline E. coli $\mathrm{DH} 5 \alpha$ & E. coli, $\alpha$-complementation & Fermentase (USA) \\
\hline Pichia pastoris & Protein expression host & Invitrogen (USA) \\
\hline Saccharomyces cerevisiae & Native Inveratse source & Sigma (USA) \\
\hline \multicolumn{3}{|l|}{ Plasmid } \\
\hline pPink $\alpha-H C$ & For integration in $P$. pastoris & Invitrogen (USA) \\
\hline \multicolumn{3}{|l|}{ Oligonucleotide primers } \\
\hline INV-P Forward & 5'-TCTATGACTAACGAAACTTCTG-3' & \\
\hline INV-P Reverse & 5'-CTTAACTTCTCTAACTTGGAAC-3' & \\
\hline $5^{\prime}$ Aox 1 primer & 5'-GACTGGTTCCAATTGACAAGC-3' & \\
\hline $3^{\prime}$ Aox 1 primer & 5'-GCAAATGGCATTCTGACATCC-3' & \\
\hline
\end{tabular}


Fig. 1 Invertase Amino acid sequence. a The amino acid sequence of native protein and its $\mathrm{N}$-terminal native signal peptide (Underlined). b The amino acid sequence of synthetic invertase protein of $P$. pastoris $(\mathrm{N}$-terminal alpha mating factor signal peptide of $S$. cerevisiae and His tag in the C-terminal are underlined) a Amino acid sequence of native Saccharomyces cerevisiae SUC2 gene (Gene Bank CAA87030.1)

MLLQAFLFLLAGFAAKISASMTNETSDRPLVHFTPNKGWMNDPNGLWYDEKDAKWHLYFQ YNPNDTVWGTPLFWGHATSDDLTNWEDQPIAIAPKRNDSGAFSGSMVVDYNNTSGFFNDT IDPRQRCVAIWTYNTPESEEQYISYSLDGGYTFTEYQKNPVLAANSTQFRDPKVFWYEPS QKWIMTAAKSQDYKIEIYSSDDLKSWKLESAFANEGFLGYQYECPGLIEVPTEQDPSKSY WVMFISINPGAPAGGSFNQYFVGSFNGTHFEAFDNQSRVVDFGKDYYALQTFFNTDPTYG SALGIAWASNWEYSAFVPTNPWRSSMSLVRKFSLNTEYQANPETELINLKAEPILNISNA GPWSRFATNTTLTKANSYNVDLSNSTGTLEFELVYAVNTTQTISKSVFADLSLWFKGLED PEEYLRMGFEVSASSFFLDRGNSKVKFVKENPYFTNRMSVNNQPFKSENDLSYYKVYGLL DQNILELYFNDGDVVSTNTYFMTTGNALGSVNMTTGVDNLFYIDKFQVREVK

b Amino acid sequence of synthetic Saccharomyces cerevisiae SUC2 gene in P.pastoris

MRFPSIFTAVLFAASSALAAPVNTTTEDETAQIPAEAVIGYSDLEGDFDVAVLPFSNSTNNGLLF INTTIASIAAKEEGVSLEKRSMTNETSDRPLVHFTPNKGWMNDPNGLWYDEKDAKWHLYFQ YNPNDTVWGTPLFWGHATSDDLTNWEDQPIAIAPKRNDSGAFSGSMVVDYNNTSGFFNDT IDPRQRCVAIWTYNTPESEEQYISYSLDGGYTFTEYQKNPVLAANSTQFRDPKVFWYEPS QKWIMTAAKSQDYKIEIYSSDDLKSWKLESAFANEGFLGYQYECPGLIEVPTEQDPSKSY WVMFISINPGAPAGGSFNQYFVGSFNGTHFEAFDNQSRVVDFGKDYYALQTFFNTDPTYG SALGIAWASNWEYSAFVPTNPWRSSMSLVRKFSLNTEYQANPETELINLKAEPILNISNA GPWSRFATNTTLTKANSYNVDLSNSTGTLEFELVYAVNTTQTISKSVFADLSLWFKGLED PEEYLRMGFEVSASSFFLDRGNSKVKFVKENPYFTNRMSVNNQPFKSENDLSYYKVYGLL DQNILELYFNDGDVVSTNTYFMTTGNALGSVNMTTGVDNLFYIDKFQVREVK $(\mathrm{w} / \mathrm{v})$ YNB, $0.00,004 \%(\mathrm{w} / \mathrm{v})$ biotin, and $0.5 \%(\mathrm{v} / \mathrm{v})$ methanol].

\section{Chemical and enzymes}

DNA restriction enzymes and T4 DNA Ligase were purchased from Vivantis Technologies Co. (Malaysia). Taq DNA polymerase, DNA Ladders and Protein markers were from Fermentase Thermo Fermentase (USA). Endoglycosidase $\mathrm{H}$ (Endo $\mathrm{H}$ ) was purchased from New England Biolabs (Beverly, MA, USA).

Native invertase was purchased from Sigma-Aldrich (USA) for using as positive control enzyme in kinetic experiments. Oligonucleotides were synthesized at TAD Copenhagen A/S (Denmark). Sucrose was from Merck (Darmstadt, Germany) and other chemicals were obtained from Merck (Darmstadt, Germany) or Sigma Chemical Co. (St Louis, MO, USA).

\section{Construction of invertase expression vector}

The SUC2 gene of $S$. cerevisiae, encoding invertase was designed according to codon preference of $P$. pastoris excluding the sequence of the $\mathrm{N}$-terminal pre-pro-sequence signal peptide and His-tag in the $\mathrm{C}$ terminus for enabling purification of the expressed invertase directly from growth medium by affinity chromatography. Designed gene (Gene Bank Accession No. CAA87030) was synthesized by Gene Art Company (Germany).

The synthetic SUC2 gene in PUC57 vector was transformed to $E$. coli strain DH5 $\alpha$ and transformants were screened in LB media supplemented with ampicillin (100 $\mu \mathrm{g} / \mathrm{ml})$.
After performing colony PCR for confirmation of the transformed clones containing PUC-SUC2, with specific forward (INV-F) and reverse (INV-R) primers (Table 1). Plasmid extraction was carried out by GF1 Nucleic Acid extraction kit (Vivantis Technologies Co. Malaysia) and digested with KpnI/XhoI. The digested product was separated by $1 \%$ agarose gel electrophoresis and gel slice containing the expected size band (1550 bp) was excised and ligated into pPink $\alpha-\mathrm{HC}$, expression vector contained the pro-pre-sequence of S.cervisiae $\alpha$ mating factor under the control of methanol-inducible alcohol oxidase (AOX1) promoter for expressing the inserted foreign gene in yeast (Fig. 1) which had been digested with the same restriction enzymes. The ligated product was used to transform $E$. coli DH5 $\alpha$ competent cells, and the transformed cells were plated on LB media with ampicillin. The correct transformants were checked By PCR. The PCR conditions were: $95{ }^{\circ} \mathrm{C}$ for $7 \mathrm{~min}$ for one cycle and then continued by $95{ }^{\circ} \mathrm{C}$ for $1 \mathrm{~min}, 55^{\circ} \mathrm{C}$ for $40 \mathrm{~s}$ and $72{ }^{\circ} \mathrm{C}$ for $35 \mathrm{~s}$ for 30 cycles. The Sequence of PCR product was confirmed by DNA sequencing (Applied Biosystem, ABI, CA, USA). Finally, the recombinant vector was obtained, it was later confirmed by sequencing with AOX primers (Table 1). DNA manipulation was performed according to the standard procedure (Sambrook et al. 1989).

\section{Expression of recombinant enzyme}

For transformation to $P$. pastoris, $1 \mu \mathrm{g}$ of pPink $\alpha-S U C 2$ recombinant expression vector was linearized using Vha $464 \mathrm{I}$ at $37{ }^{\circ} \mathrm{C}$ for $2 \mathrm{~h}$, after which linearized plasmids were purified by GF1 Nucleic Acid extraction kit (Vivantis

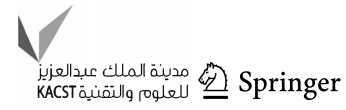


Technologies Co. Malaysia) which was according to the manufacturer's protocol. For the expression of recombinant protein, the competent adenine gene deficient $P$. pastoris was prepared and transformed with the plasmid pPink $\alpha-\mathrm{HC}$ using the electroporation method (BTX, ECM630, USA) at $1850 \mathrm{~V}, 200 \Omega$ and $25 \mu \mathrm{F}$ with $2 \mathrm{~mm}$ cuvette. Immediately, after pulsing $1 \mathrm{ml}$ of cold $1 \mathrm{M}$ sorbitol was added to the sample and incubated at $30{ }^{\circ} \mathrm{C}$ for $60 \mathrm{~min}$, then cuvette contents were plated on PAD medium (Pichia Adenine Dropout). The plates were incubated for $3-7$ days at $30{ }^{\circ} \mathrm{C}$, until distinct colonies are formed. The linearized pPink $\alpha$ $\mathrm{HC}$ was transformed to $P$. pastoris as a negative control.

\section{Screening of transformed yeasts}

Integration of SUC2 to yeast host genomes was investigated by extraction of genomic DNA of transformed $P$. pastoris which was grown on YPD medium. Yeasts genomic DNA were extracted by glass beads method as described by Hoffman and Winston (1987) and the presence of SUC2 gene was confirmed by PCR using specific primers (Table 1). The PCR conditions were: $95{ }^{\circ} \mathrm{C}$ for $5 \mathrm{~min}$ for one cycle, then continued by $95^{\circ} \mathrm{C}$ for $30 \mathrm{~s}$, $55^{\circ} \mathrm{C}$ for $35 \mathrm{~s}$ and $72{ }^{\circ} \mathrm{C}$ for $40 \mathrm{~s}$ for 30 cycles. The amplified PCR product was checked by $1 \%$ agarose gel electrophoresis and the expected size band (1550 bp) was observed. The Sequence of amplified PCR product was confirmed by DNA sequencing (Applied Biosystem, ABI, CA, USA).

\section{Expression of recombinant invertase}

Basically, the correct recombinant yeasts were cultured in BMGY medium at $30{ }^{\circ} \mathrm{C}$ in shaker incubator at $220 \mathrm{rpm}$ until the $A_{600}$ value reached 2.0. Culture samples were then centrifuged at $3000 \mathrm{~g}$ for $5 \mathrm{~min}$, after which the growth medium was removed and the cells were resuspended in the BMMY medium and grown at $30{ }^{\circ} \mathrm{C}$ for 4 days. Methanol $[(0.5 \%(\mathrm{v} / \mathrm{v})$ of the growth medium] was added to the culture every $24 \mathrm{~h}$ to induce invertase gene expression.

\section{Protein purification and detection}

Purification of the recombinant invertase was carried out by affinity chromatography. The methanol-induced cultures were centrifuged at $5000 \mathrm{~g}$ for $5 \mathrm{~min}$, after which the invertase-containing supernatant was lyophilized and resuspended dry powder in Binding buffer [20 mM phosphate, $20 \mathrm{mM}$ imidazole, $500 \mathrm{mM} \mathrm{NaCl}$ (pH 7.4)] and latter concentrated by ultrafiltration Amicon Millipore $(30 \mathrm{kDa}$ cut off).

The concentrated enzyme solution was pumped to AKTA Purifier Fast Protein Liquid Chromatography system (Amersham bioscience, USA) by applying a HisTrap FF Crude 5-ml column (GE Healthcare, USA) equilibrated with Binding buffer, and after sample injection, it was washed with 5 column volumes of Binding buffer, followed by 2.5 column volumes of $10 \%$ Elution buffer [20 mM phosphate, $500 \mathrm{mM}$ imidazole, $500 \mathrm{mM}$ $\mathrm{NaCl}$ ( $\mathrm{pH}$ 7.4)]. The enzyme of interest was eluted with a linear gradient from 10 to $100 \%$ Elution buffer in 5 column volumes, and finally, the column was washed with 5 column volumes of $100 \%$ Elution buffer (Lafraya et al. 2011). Then, the fractions with invertase activity were collected and $10 \%$ SDS-PAGE was performed according to the method of Laemmli (Laemmli 1970) for resulting fractions and stained by silver nitrate. Sample containing a band with the expected size of enzyme was dialyzed (1/ 10,000) against a buffer containing $50 \mathrm{mM}$ Sodium acetate ( $\mathrm{pH} 4.8$ ) and kept at $-20{ }^{\circ} \mathrm{C}$ for further analysis.

\section{Determination of Invertase activity}

Invertase activity was assayed by $20 \mathrm{~min}$ incubation of $0.1 \mathrm{ml}$ (1:10) diluted enzyme solution with $0.9 \mathrm{ml}$ of sucrose in $50 \mathrm{mM}$ sodium acetate buffer $(\mathrm{pH} 4.8)$ at $50{ }^{\circ} \mathrm{C}$. Reducing sugars were quantified by addition of dinitrosalicylic acid reagent and the reaction was terminated by heating in $100{ }^{\circ} \mathrm{C}$ boiling water bath for $10 \mathrm{~min}$. Finally, absorbance was read at $540 \mathrm{~nm}$ in spectrophotometer (Sainz-Polo et al. 2013). One unit of invertase was defined as the amount of enzyme that catalyzed the formation of $1 \mu \mathrm{mol}$ of reducing sugar/min from sucrose at $50{ }^{\circ} \mathrm{C}$ and $\mathrm{pH}$ 4.8. The standard curve was prepared with glucose $(0.25-2.5 \mathrm{mM})$.

The protein concentration was determined spectrophotometrically using an adsorption at $280 \mathrm{~nm}$ according to the method proposed by Gill and von Hippel (Gill and von Hippel 1989) with bovine serum albumin serving as the standard protein.

Enzymatic deglycosylation of the recombinant invertase was accomplished by incubating $5 \mu \mathrm{g}$ of the invertase with 0.5 units Endo $\mathrm{H}$ (Biolab) for $18 \mathrm{~h}$ at $37^{\circ} \mathrm{C}$ according to manufacturer instruction, invertase band migration shift was studied by SDS-PAGE. After which the resolved proteins were obtained with Coomassie blue R-250.

\section{Characterization of the purified recombinant enzyme}

Effect of $\mathrm{pH}$ on activity and stability of the recombinant invertase

The effect of $\mathrm{pH}$ on invertase activity was determined in the $\mathrm{pH}$ range of $3-8$, using $50 \mathrm{mM}$ sodium acetate buffer (pH 3.0-5.0), sodium phosphate (6.0-7.0) and Tris-Hcl 
(8.0) and enzyme activity was measured after $20 \mathrm{~min}$ in $50{ }^{\circ} \mathrm{C}$. To study the effect of $\mathrm{pH}$ on the stability, the enzyme was incubated for $30 \mathrm{~min}$ at $30{ }^{\circ} \mathrm{C}$ in $50 \mathrm{mM}$ buffers at different $\mathrm{pH}$ in the absence of substrate, and after which calculated the residual activity under assay condition.

\section{Effect of temperature on activity and stability of the recombinant invertase}

The optimum temperature of invertase was measured in $50 \mathrm{mM}$ sodium acetate buffer at $\mathrm{pH} 4.8$ over a temperature range of 20 to $80{ }^{\circ} \mathrm{C}$ with interval of $5{ }^{\circ} \mathrm{C}$. Thermal stability of enzyme was studied by incubating the purified enzyme samples in the absence of substrate at seven different incubation temperatures ranged from 20 to $80{ }^{\circ} \mathrm{C}$ for $1 \mathrm{~h}$ and immediately samples were placed on ice for $20 \mathrm{~min}$, after which remaining activity of invertase measured under standard assay condition. Long time invertase thermal stability determined through 70 and $80{ }^{\circ} \mathrm{C}$ heat treatment from 1 to $60 \mathrm{~min}$, subsequently invertase heat stability was determined according to samples residual activity.

The kinetic parameters, $\mathrm{K}_{\mathrm{m}}$ and $\mathrm{V}_{\max }$, Michaelis-Menten constants of invertase were determined at $\mathrm{pH} 4.8$ with $50 \mathrm{mM}$ sodium acetate buffer for five parallel series of recombinant invertase samples.

\section{Results and discussion}

\section{Construction of vector for invertase expression in methylotrophic yeast}

The SUC2 gene (1550 bps) with open reading frame encoding 512 amino acid residues and 6 histidine residues in $\mathrm{C}$ terminus that enable purification of the expressed proteins by affinity chromatography, was designed according to methylotrophic yeast Pichia pastoris codon bias and for the first time in studies designed gene was optimized by Gene Optimizer software (Fig. 1). In others studies optimized synthetic gene was used for producing extracellular enzymes like cellulase and phytase which were succeed to express recombinant proteins (Akbarzadeh et al. 2013; Hesampour et al. 2014, 2015). Design of 6 histidine residues were successfully applied at C-terminal of the protein and enabled us to purify active enzyme, so probably small His-Tag in C terminus of invertase had no influence on the protein conformation for its activity (Huang et al. 2003). The synthesized SUC2 gene was digested and cloned into pPink- $\alpha \mathrm{HC}$ expression vector, afterwhich for efficient and stable expression of invertase, the recombinant pPink $\alpha \mathrm{HC}-\mathrm{SUC} 2$ construct was linearized

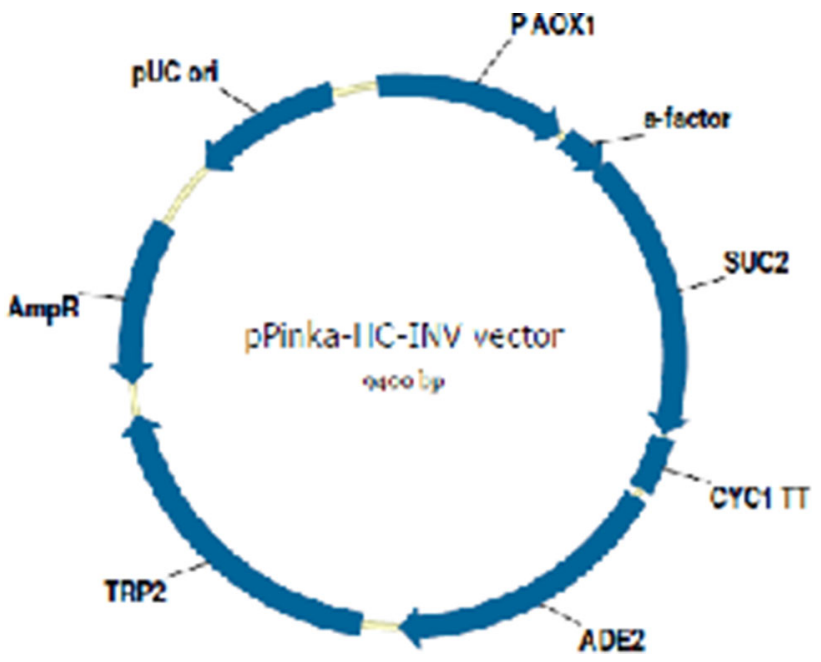

Fig. 2 Construction of pPink $\alpha-H C$ INV expression vector

by Vha 464I restriction enzyme digestion at TRP2 region of plasmid and used to integrate in P. pastoris genome by genome replacement. The pPink $\alpha \mathrm{HC}-\mathrm{SUC} 2$ was linearized by Vha 464I restriction enzyme digestion at TRP2 region of plasmid and transformed to $P$. pastoris cells. pPink- $\alpha \mathrm{HC}$ contains a methanol-inducible alcohol oxidase (AOX1) promoter for expression of the invertase gene in yeast and for extracellular invertase secretion, $\alpha$-mating factor from $S$. cerevisiae was used in the $\mathrm{N}$ terminus of recombinant expression construct (Fig. 2). The S. cerevisiae $\alpha$-mating factor pre-pro-sequence provide secretion of numerous heterologous expressed products in $S$. cerevisiae and $P$. pastoris (Huang et al. 2003; Wang et al. 2005).

To confirm the correct $S U C 2$ gene integrated in yeasts genome, the genomes of yeasts which had been formed colonies in YPD media, extracted and screened by use of $S U C 2$ specific primers through PCR process. PCR product bands in $1 \%$ agarose gel electrophoresis, revealed the successful genome integration (Fig. 3). In the next step, positive colonies were selected for subsequent studies.

\section{Expression of recombinant invertase in methylotrophic yeast}

Extra cellular Invertase production by transformed Pichia cells was studied in BMGY and BMMY expression media in the presence of methanol for induction of AOX1 promoter to overexpress the inserted invertase gene. Methanol was added to the culture every $24 \mathrm{~h}$. Enzyme quantitative assays and SDS-PAGE were carried out after each day by methanol induction for determination of the highest invertase expression profile. Our results indicated that the recombinant active invertase expressed successfully in $P$. pastoris and secreted into the growth medium and as shown in Fig. 4a, it can be observed that extracellular 


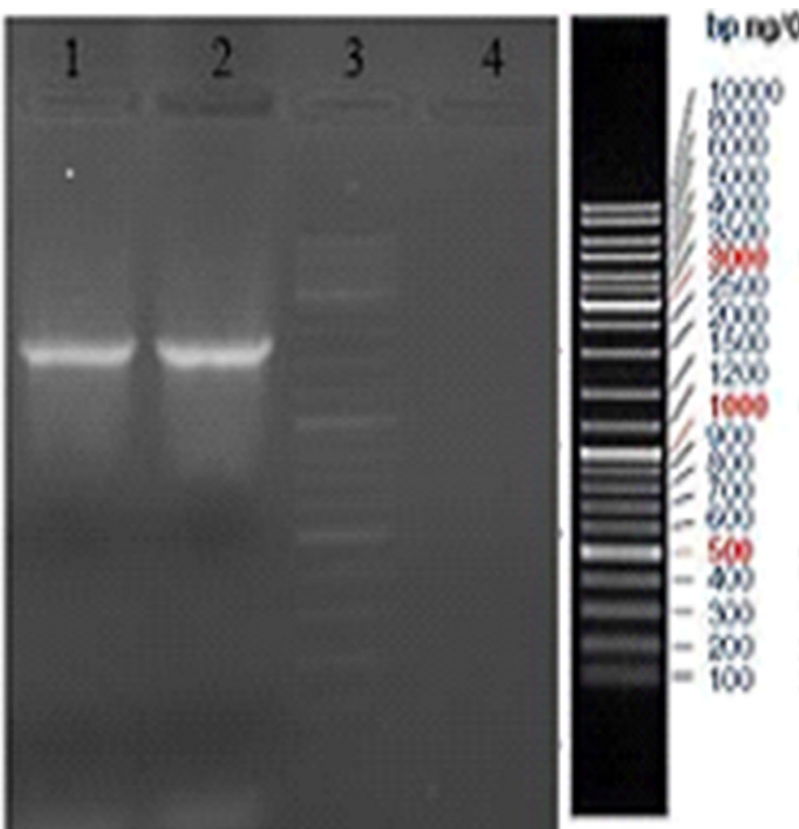

Fig. 3 Yeast genome integrant PCR analysis. Lane 1 PCR product of transformant $P$. pastoris. Lane 2 pPink-INV plasmid PCR product as a positive control. Lane 3 DNA size marker1 $\mathrm{kb}$. Lane 4 Transformed $P$. pastoris by pPink $\alpha$-HC Plasmid PCR as negative control

invertase reached maximum activity after 4 days methanol induction ( $46.61 \mathrm{U} / \mathrm{mg}$ in $200 \mathrm{ml}$ culture), followed by a decline in the enzyme activity till the 5th day of methanol induction. The results of $P$. pastoris supernatant SDSPAGE showed that the smear bands with molecular size ranging from 85 to $95 \mathrm{kDa}$ (Fig. $4 \mathrm{~b}$ ), whereas native invertase of $S$. cerevisiae with a $50 \%$ carbohydrate content has a molecular mass of approximately $110-120 \mathrm{kDa}$ that was included in the same gel (Fig. 4c) which in several studies were stated that invertase secreted by wild-type Saccharomyces strains consists of 100-140 kD (Trimble and Maley 1977) acid invertases have been shown to be glycosylated. Moreover, post-translational glycosylation is also involved in the secretion of heterologously expressed proteins from $P$. pastoris, though the glycosylation level and carbohydrate structures on the secreted recombinant proteins vary from protein to protein and this difference in molecular mass of enzymes can be concluded from the variant pattern of yeast glycosylation (Montesino et al. 1998). To determine the molecular size of distribution oligosaccharides associated with the recombinant invertase, the protein was deglycosylated by treatment with Endo H. SDS-PAGE analysis revealed that a shift in the apparent molecular mass to approximately $60 \mathrm{kDa}$ according to its amino acid composition (Fig. 4b) and showed a similar electrophoretic mobility and molecular weight with the native $S$. cerevisiae invertase that was treated with Endo $\mathrm{H}$ by the same manner (Reddy et al.
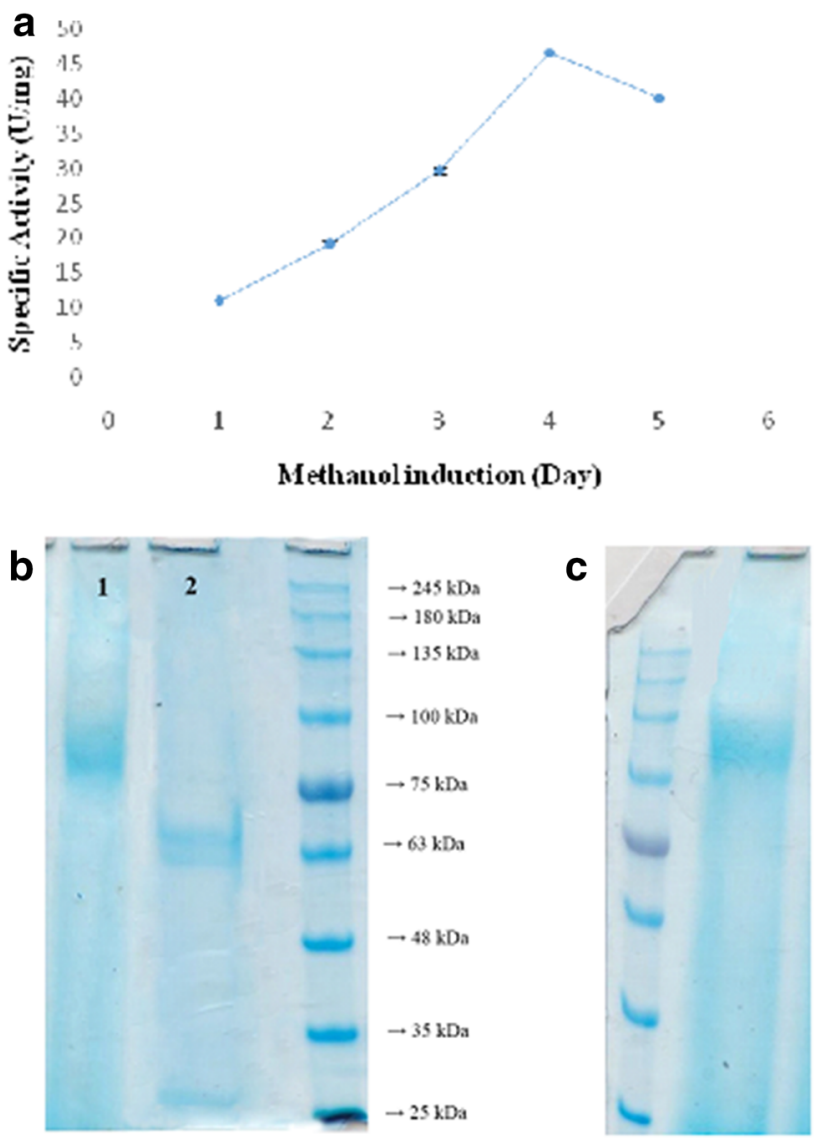

Fig. 4 a Extracellular invertase activity by methanol induction. b SDS-Polyacrylamide gel electrophoresis of recombinant invertase from $P$. pastoris. Lane 1 Recombinant expressed Invertase. Lane 2 Recombinant expressed Invertase treatment with Endo H. c SDSPAGE of native invertase from $S$. cerevisiae

1988; Perez et al. 2001). Translation of the recombinant invertase sequence produces a protein with 518 amino acids and molecular mass of close to $60 \mathrm{kDa}$, proposing the presence of $\mathrm{N}$-linked carbohydrate contributed approximately $30-35 \%$ for recombinant invertase of $P$. pastoris to the total weight of the enzyme.

\section{Effect of pH on invertase activity and stability}

The optimum $\mathrm{pH}$ invertase activity was evaluated by maintaining the enzyme in different $\mathrm{pH}$ reagent range of 3.0-8.0 (Fig. 5a). The results indicated that more than $50 \%$ residual activity of enzyme in $\mathrm{pH} 3.0-6.5$ with optimum activity at $\mathrm{pH}$ 4.8. Heterologous expressed invertase has exhibited the same $\mathrm{pH}$ pattern as the acid invertase and has potential to remain its activity in broad range of acidic to neutral environments that can be applied in bioethanol production, pharmaceutical industry and submerged fermentation. (Park and Sato 1982; Mona et al. 2009; Uma et al. 2010a; Patil et al. 2012). 
For determination of long-term $\mathrm{pH}$ stability of the enzyme, the protein was placed at different $\mathrm{pH}$ in the absence of substrate. Extracellular invertase was found to
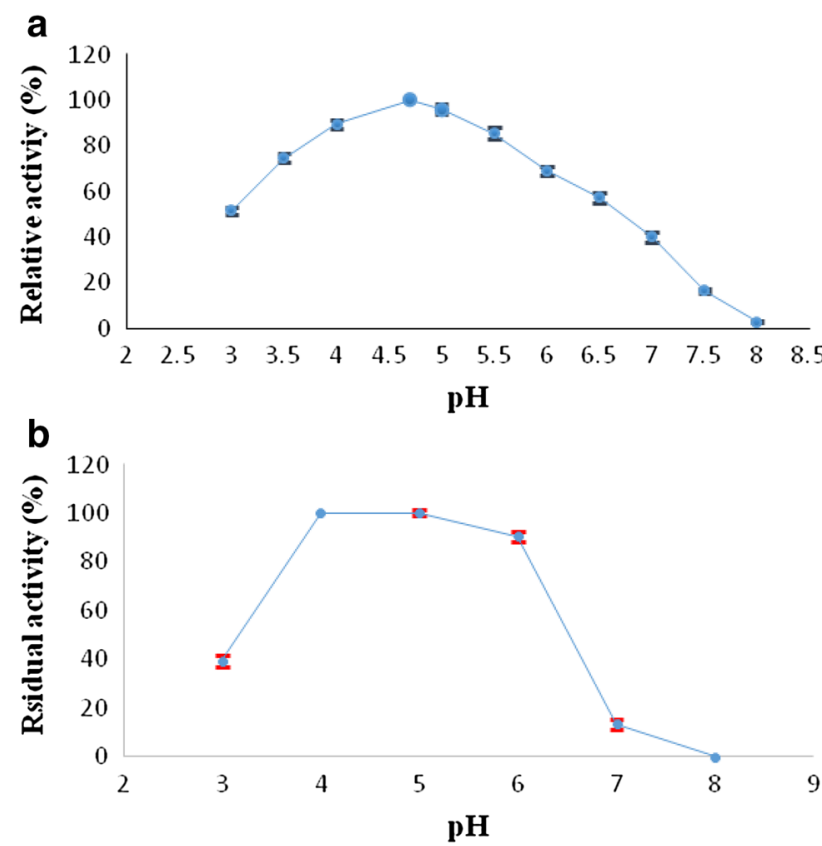

Fig. 5 Characterization of recombinant Invertase expressed in $P$. pastoris, effect of different $\mathrm{pH}$ on recombinant Invertase assay. a Effect of different $\mathrm{pH}$ on recombinant Invertase activity. b Residual activity of recombinant Invertase after treatment for $30 \mathrm{~min}$ at different $\mathrm{pH}$

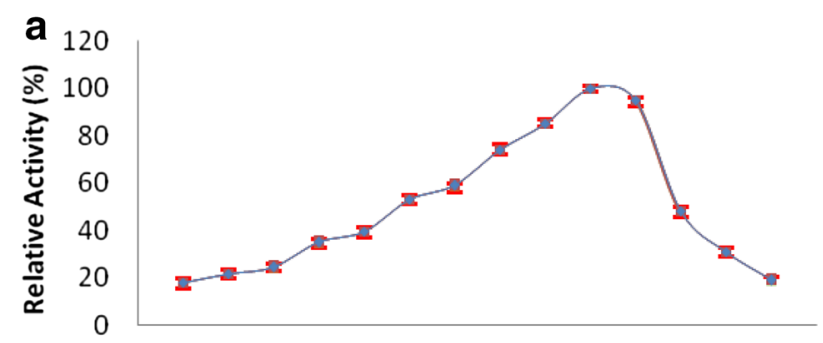

$101520253035404550556065707580 \quad 85$

Temprature ${ }^{\circ} \mathrm{C}$

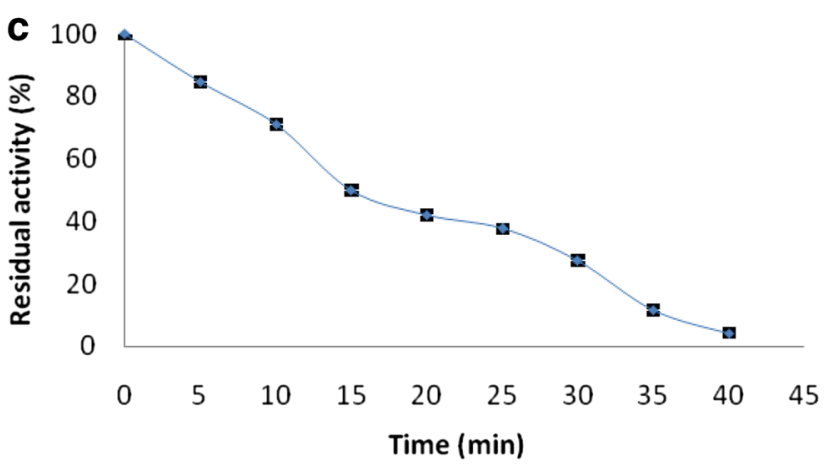

be stable at $\mathrm{pH} 4.0-6.0$ with more than $90 \%$ residual activity after $30 \mathrm{~min}$ (Fig. 5b). The recombinant expressed invertase showed the acidic $\mathrm{pH}$ profile compared with native $S$. cerevisiae genus invertases which have recorded with optima pH 6.0 (Mona et al. 2009; Shankar et al. 2014) and also maximum Aspergillus sp. Invertases activity were evaluated at pH 6.0 (Uma et al. 2010a, 2012; Patil et al. 2012) but similar $\mathrm{pH}$ profile observation have been reported for invertase production by recombinant A.nigersucl gene (Driouch et al. 2010) and invertase -encoding of AINV gene Arxula adeninivorans (Boer et al. 2004).

\section{Effect of temperature on invertase activity and stability}

To determine the effect of temperature on the enzyme activity and stability, two series of experiments were carried out. In the first series of experiments (determination of optimum temperature), the effect of different temperatures range of $20-80{ }^{\circ} \mathrm{C}$ on purified recombinant invertase activity was studied. Temperature behaviour of recombinant invertase showed maximum activity at $60{ }^{\circ} \mathrm{C}$ (Fig. 6a), whereas Saccharomyces genus, have optimum growth temperatures at $30-35{ }^{\circ} \mathrm{C}$ and maximum tolerate temperatures $45-48{ }^{\circ} \mathrm{C}$ (Salvado et al. 2011; Timerman 2012). Also this optimum temperature is significantly higher than optima temperature reported for some other microbial sources $37^{\circ} \mathrm{C}$ in Lactobacillus reuteri (Gines
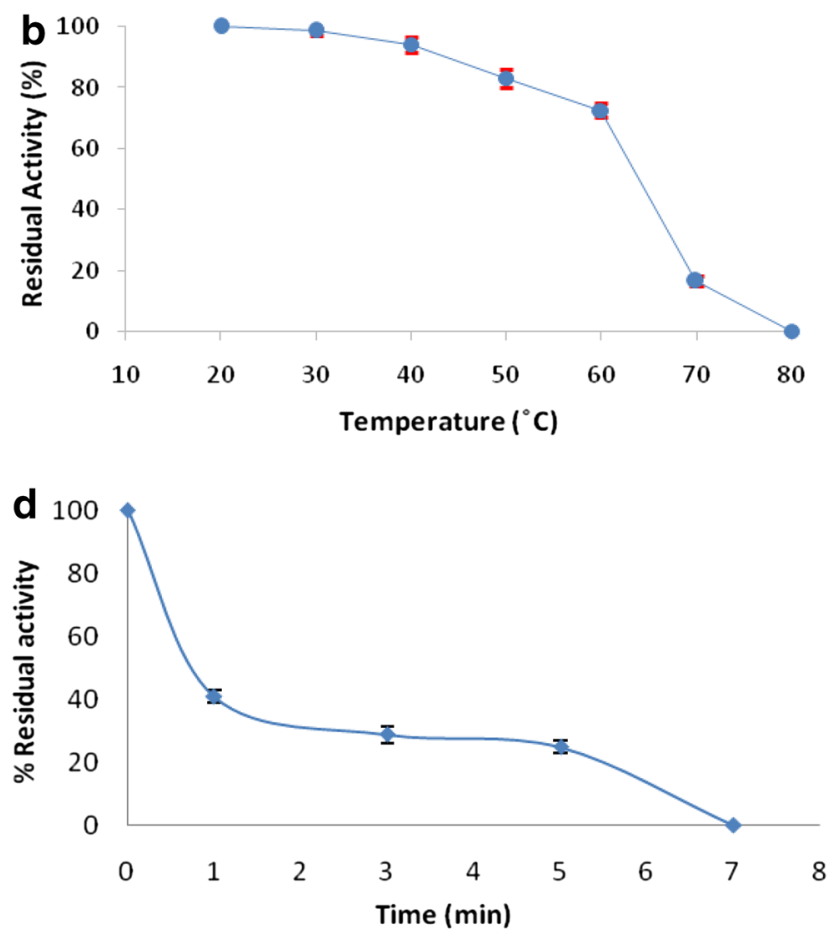

Fig. 6 a The effect of temperature on the activity of the recombinant enzyme. b Thermal stability of recombinant invertase in the absence of substrate. c Heat stability of enzyme activity at $70{ }^{\circ} \mathrm{C}$. d Heat stability of enzyme activity at $80{ }^{\circ} \mathrm{C}$ 
et al. 2000) and Actinomycete strain (Kaur and Sharma 2005), $45{ }^{\circ} \mathrm{C}$ Torulaspora pretoriensis (Oda and Tonomura 1994). Recombinant invertase activity declined at higher temperature than $65^{\circ} \mathrm{C}$ and decreased activity to $47.5 \%$ at $70{ }^{\circ} \mathrm{C}$. The original activity was retained approximately above $60 \%$ from 45 to $65^{\circ} \mathrm{C}$ (Fig. 6a), this high optimum temperature is important from the biological point of view.

In the second series of experiments, the thermal stability of the purified extracellular invertase in the absence of substrate was examined. More than $80 \%$ activity of the enzyme was remained up to $50{ }^{\circ} \mathrm{C}$ for $30 \mathrm{~min}$ and about $72 \%$ of the residual activity was remained at $60{ }^{\circ} \mathrm{C}$. The results of thermo stability experiments, revealed that the thermal inactivation of enzyme with midpoint at $64{ }^{\circ} \mathrm{C}$ (Fig. 6b). The activity decreased rapidly after incubation of enzyme at temperature higher than $60{ }^{\circ} \mathrm{C}$ and after $10 \mathrm{~min}$ of incubation at $80^{\circ} \mathrm{C}$, no invertase activity was recovered, whereas native invertase lost its activity at temperature higher than $48{ }^{\circ} \mathrm{C}$ heat treatment. Thermo stability behaviours of recombinant enzyme revealed that the expressed invertase in $P$. pastoris is more thermostable than the native invertase of $S$. cerevisiae (Shankar et al. 2014).

To investigate long time thermal stability of recombinant invertase, purified enzyme was incubated at 70 and $80{ }^{\circ} \mathrm{C}$ for $1-60 \mathrm{~min}$ and remaining activity was measured. Heat stability studies determined that after $30 \mathrm{~min}$ of incubation at $70{ }^{\circ} \mathrm{C}$, enzyme activity declined to $13 \%$ of its activity (Fig. 6c), recombinant invertase have half-life

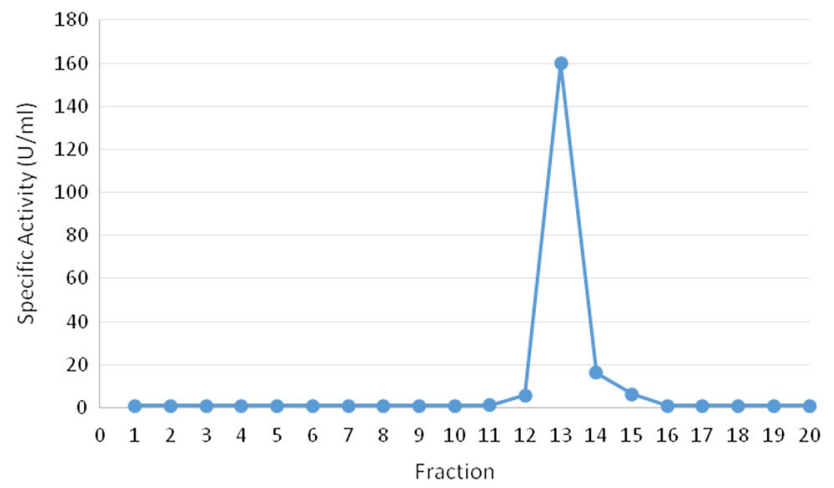

Fig. 7 Elution profile of purified recombinant Invertase fractions by a His-tag FPLC of $15 \mathrm{~min}$ and $45 \mathrm{~s}$ at 70 and $80{ }^{\circ} \mathrm{C}$, respectively (Fig. $6 \mathrm{c}$, d). This enzyme stability was more than the heat stability of recombinant invertase that illustrated by Acosta et al. (2000) which reported that the invertase activity of SUC2 gene that was expressed in Hansenula polymorpha cells declined rapidly in $80^{\circ} \mathrm{C}$ after $2 \mathrm{~min}$. So, bearing in mind that the recombinant invertase is stable in low $\mathrm{pH}$ and high temperature with optimum in $60{ }^{\circ} \mathrm{C}$, whereas native invertase from different sources inactivated at high temperatures and unable to have an activity in acidic $\mathrm{pH}$ range (Salvadó et al. 2011) the recombinant expressed invertase could be an ideal choice for industrial applications.

\section{Purification and kinetic characteristic}

For characterization, recombinant invertase was purified by His tag affinity chromatography (Lafraya et al. 2011) using 6 histidine residues at $\mathrm{C}$ terminus of protein, elution profile of purified fractions on affinity chromatography were obtained. As shown in Fig. 7, eluted recombinant enzyme showed a single peak and silver staining of the column fractions revealed that the protein band in fraction with $300 \mathrm{mM}$ imidazol, which was estimated as the recombinant enzyme migrates as a distinct $85-95 \mathrm{kDa}$ in SDS-PAGE. It seems that the presence of low smear band is due to glycosylation which after treated with Endo $\mathrm{H}$, specific single band was obtained.The specific activity of the final purified preparation was $178.38 \mathrm{U} / \mathrm{mg}$, representing a total purification factor of 4.46 (Table 2).

In the present study, the Kinetic constant, $K_{m}$ and $V_{\max }$ of recombinant invertase calculated at different concentration of sucrose substrate and maximum enzyme activity was obtained at sucrose concentration of $5 \%$. The rate of sucrose hydrolysis decreased by increasing of the substrate concentration. The reason might be due to the production of higher concentration of Glucose and Fructose in the medium which resulting in glucose-induced repression of invertase (Ikram and Sikander 2005; Mona et al. 2009).

The $K_{m}$ value of the $P$. pastoris recombinant invertase was found to be a considerable $19 \mathrm{mM}$ while its $V_{\max }$ was $300 \mu \mathrm{mol} \mathrm{min}{ }^{-1} \mathrm{mg}^{-1}$ with kinetic efficiency $\left(K_{\text {cat }} / K_{m}\right)$ of $13.15 \mathrm{~s}^{-1} \mathrm{mmol}^{-1}$.

Table 2 The data were obtained from the supernatant of $200 \mathrm{ml}$ culture of methanol-induced P. pastoris transformants

\begin{tabular}{lllll}
\hline Steps & Invertase Activity (Units) & Total protein (mg) & Specific activity (Units/mg) & Purification (Fold) \\
\hline Centrifugal supernatant of the culture & 65.26 & 1.40 & 46.61 & 1 \\
$70 \%$ Ammonium sulfate precipitation & 35.71 & 0.97 & 36.82 & 0.79 \\
Ultrafiltration & 49.00 & 1.21 & 59.30 & 1.27 \\
His-tag FPLC & 80.89 & 0.453 & 178.56 & 3.83 \\
\hline
\end{tabular}

One unit of invertase is defined as the amount of enzyme that hydrolysed sucrose to yield $1 \mu \mathrm{mol}$ of reducing sugar/min at $50{ }^{\circ} \mathrm{C}$ and $\mathrm{pH} 4.8$ 
The lower $K_{m}$ value of $P$. pastoris recombinant invertase in comparison with native invertase $k_{m}$ value which was $25 \mathrm{mM}$, indicated that higher affinity to sucrose and sufficient degradation rate in lower substrate concentration. This might reflect a change in the folded structure of the recombinant enzyme that was caused by the C-terminal His-Tag and also difference in the affinity of the native and recombinant enzyme for sucrose might be affected by its different extent of glycosylation status which can have significant role on invertase substrate binding site conformation (Huang et al. 2003).

\section{Conclusion}

Although invertase has been produced by different microorganisms (Kim et al. 2000), however, the low expression level of invertase in the native hosts make these organisms unsuitable to produce heterologous invertase for biotechnological applications and because of the interest in use of biologically produced invertase in confectionary and dairy, pharmaceutical, prebiotics and bioethanol production, highly efficient and cost-effective process of enzyme production by recombinant micro-organisms have been developed (Gehlawat 2001).

Among microorganisms, methylotrophic yeast $P$. pastoris expression host has some advantages that includes strong inducible promoter, post-translational modification and high expression system in a cost effective medium which were strong reasons that we persuaded to choose this effective system as a host for invertase optimum conditions of expression (Rodriguez et al. 1996; Daly and Hearn 2005).

Biochemical characterization of purified recombinant invertase, indicated that enzyme with maximum activity at $60{ }^{\circ} \mathrm{C}$ and broad $\mathrm{pH}$ range activity from acidic to neutral with optimum $\mathrm{pH}$ at 4.8 . The recombinant invertase high temperature and low $\mathrm{pH}$ optima are advantageous for industrial high invert sugar and fructose syrup production, as all these conditions prevent microbial contamination and undesired colour formation (Vandamme and Derycke 1993).

Also thermostable enzymes can improve productivity of biotechnological processes because the rate of a reaction typically doubles with every $10{ }^{\circ} \mathrm{C}$ increase in temperature (Tananchai and Chisti 2010). It is an important objective in industrial criteria which was obtained in this study and the recombinant expressed invertase has the ability to withstand and remain its activity at high temperature and can be a valuable candidate for industrial applications.

Acknowledgments This work was supported by the Protein Research Centre of Shahid Beheshti University and National Institute of
Genetic Engineering and Biotechnology. We are thankful for providing lab facilities for this research work. We express our deep gratitude to Dr. Shohre Khorshidi for her stylistic suggestions in the preparation of the manuscript and her expert editing.

\section{Compliance with ethical standards}

Conflict of interest The authors declare that they have no conflict of interest in the publication.

Open Access This article is distributed under the terms of the Creative Commons Attribution 4.0 International License (http:// creativecommons.org/licenses/by/4.0/), which permits unrestricted use, distribution, and reproduction in any medium, provided you give appropriate credit to the original author(s) and the source, provide a link to the Creative Commons license, and indicate if changes were made.

\section{References}

Acosta N, Beldarrain A et al (2000) Characterization of recombinant invertase expressed in methylotrophic yeasts. Biotechnol Appl Biochem 32(Pt 3):179-187

Akbarzadeh A, Ranaei SO et al (2013) Comparison of biochemical properties of recombinant endoglucanase II of Trichoderma reesei in methylotrophic yeasts, Pichia pastoris and Hansenula polymorpha. Prog Biol Sci 3(1):108-117

Boer E, Wartmann T et al (2004) Characterization of the AINV gene and the encoded invertase from the dimorphic yeast Arxula adeninivorans. Antonie Van Leeuwenhoek 86(2):121-134

Cereghino JL, Cregg JM (2000) Heterologous protein expression in the methylotrophic yeast Pichia pastoris. FEMS Microbiol Rev $24: 45-66$

Daly R, Hearn MT (2005) Expression of heterologous proteins in Pichia pastoris: a useful experimental tool in protein engineering and production. J Mol Reconition 18(2):119-138

Driouch H, Roth A et al (2010) Optimized bioprocess for production of fructofuranosidase by recombinant Aspergillus niger. Appl Microbiol Biotechnol 87:2011-2024

Gehlawat JK (2001) New technology for invert sugar and high fructose syrups from sugarcane. Indian $\mathrm{J}$ Chem Technol 8:28-32

Gill SC, von Hippel PH (1989) Calculation of protein extinction coefficients from amino acid sequence data. Anal Biochem 182:319-326

Gines SCD, Maldonado MC, Valdez GF et al (2000) Purification and characterization of invertase from Lctobacillus reuteri CRL 1100. Curr Microbil 40:181-184

Gracida-Rodriguez J, Favela-Torres E et al (2006) Invertases. Enzyme Technology. Pandey A, webb C, Soccol C. R and Larroche Ch. springer, Springer science

Hesampour H, Ranaei SO et al (2014) Comparison of biochemical properties of recombinant phytase expression in the favorable methylotrophic platforms of Pichia pastoris and Hansenula polymorpha. Prog Biol Sci 4(1):95-109

Hesampour H, Ranaei Siadat SE, Malboobi MA, Mohandesi N, Arab SSH, Ghahremanpour MM (2015) Enhancement of thermostability and kinetic efficiency of Aspergillus Niger PhyA phytase by site-directed mutagenesis. Appl Biochem Biotechnol 175(5):2528-2541

Hoffman CS, Winston F (1987) A ten-minute DNA preparation from yeast efficiently releases autonomous plasmids for transformation of Escherichia coli. Gene 57(2-3):267-272 
Huang WC, Wang AY et al (2003) Expression and characterization of sweet potato invertase in Pichia pastoris. J Agric Food Chem 51(5):1494-1499

Ikram ULH, Sikander A (2005) Invertase production From a hyperproducing saccharomyces cerevisiae strain isolated from dates. Pak J Bot 37(3):749-759

Kaur N, Sharma AD (2005) Production, optimization and characterization of extracellular invertase by an actinomycete strain. J Sci Ind Res 64:515-519

Kim BW, Kwon HJ et al (2000) Production of a novel transfructosylating enzyme from Bacillus macerans EG-6. Bioprocess Eng 23:11-16

Laemmli UK (1970) Cleavage of structural proteins during assembly of the head of bacteriophage T4. Nature 227:680-685

Lafraya A, Sanz-Aparicio J et al (2011) Fructo-oligosaccharide synthesis by mutant versions of Saccharomyces cerevisiae invertase. Appl Environ Microbiol 77(17):6148-6157

Mona M, Rashad U et al (2009) Production, purification and characterization of extracellular invertase from Saccharomyses Cerevisiae NRRL Y-12632 by solid-state fermentation of red carrot residue. Aust J Basic Appl Sci 3(3):1910-1919

Montesino R, Garcia R et al (1998) Variation in N-linked oligosaccharide structures on heterologous proteins secreted by the methylotrophic yeast Pichia pastoris. Protein Expr Purif 14:197-207

Oda Y, Tonomura K (1994) Purification and characterization of invertase from Toruaspora pretoriensis YK1. Biosci Biotechnol Biochem 58:1155-1157

Park YK, Sato HH (1982) Fungal invertase as an aid for fermentation of cane molasses into ethanol. Appl Environ Microbiol 44(4):988-989

Patil M, Bhamre R et al (2012) Invertase production from Aspergillus spp M1 isolated from honeycomb. Int J Appl Biores 4:1-5

Perez JA, Rodriguez J et al (2001) Expression of Pichia anomala INV1 gene in Saccharomyces cerevisiae results in two different active forms of hypoglycosylated invertase. Arch Microbiol 175(3):189-197

Piscitelli A, Pezzella C et al (2010) Heterologous laccase production and its role in industrial applications. Bioeng Bugs 1(4):254-262

Reddy VA, Johnson RS et al (1988) Characterization of the glycosylation sites in yeast external invertase. I. N-linked oligosaccharide content of the individual sequons. J Biol Chem 263(15):6978-6985
Rodriguez L, Narciandi RE et al (1996) Invertase secretion in Hansenula polymorpha under the AOX1 promoter from Pichia pastoris. Yeast 12(9):815-822

Sainz-Polo MA, Ramirez-Escudero M et al (2013) Three-dimensional structure of Saccharomyces invertase: role of a non-catalytic domain in oligomerization and substrate specificity. J Biol Chem 288(14):9755-9766

Salvadó Z, Arroyo-López FN et al (2011) Temperature adaptation markedly determines evolution within the genus Saccharomyces. Appl Environ Microbiol 77(7):2292-2302

Sambrook J, Fritsch EF, et al (1989) Molecular cloning: a laboratory manual, 2nd ed., Cold Spring Harbor Laboratory, Cold Spring Harbor, New York

Shankar T, Thangamahti P et al (2014) Charecterization of invertase from saccharomyces cerevisiae MTCC170. Afr J Microbiol Res 8(13):1385-1393

Tananchai P, Chisti Y (2010) Stabilization of invertase by molecular engineering. Biotechnol Prog 26(1):111-117

Timerman AP (2012) The isolation of invertase from baker's yeastan introduction to protein purification strategies. Protein Purif $29-52$

Trimble RB, Maley F (1977) Subunit structure of external invertase from Saccharomyces cerevisiae. J Biol Chem 252(12): $4409-4412$

Uma C, Gomathi D, et al (2012) Production and properties of Invertase from Cladosporium cladosporioides in $\mathrm{SmF}$ using pomegranate peel waste as substrate. Asian Panific J Trop Biomed 2:605-611

Uma C, Muthulakshmi C, Gopalakrishnan VK (2010a) Fungal invertase as aid for production pf ethanol from sugarcane bagasse. Res J Microbiol 5(10):980-985

Uma C, Muthulakshmi C, Gopalakrishnan VK (2010b) Production, Purification and Characterization of Invertase by Aspergillus flavus Using Fruit Peel Waste as Substrate. Adv Biol Res $4(1): 31-36$

Vandamme EJ, Derycke DG (1993) Microbial invertase; fermentation process, properties and applications. Adv Appl Microbiol 29:139-1761

Wang LT, Wang AY et al (2005) Vacuolar invertases in sweet potato: molecular cloning, characterization, and analysis of gene expression. J Agric Food Chem 53(9):3672-3678 